\title{
A Clash of Two Generations: A Comparative Deconstructive Discourse Analysis of Three News Reports on Megawati's Critique for Indonesian Millennials
}

\author{
Bima Iqbal Khadafi \\ Sanata Dharma University, INDONESIA \\ e-mail: bimaiqbalk@gmail.com
}

\begin{abstract}
This paper aims to demystify the hegemony in the news report covering the critique of the former president of Indonesia, Megawati Soekarnoputri, on Indonesian millennial for the lack of their contribution to the country. Applying a combination of genre, deconstruction, and dynamic perspective of ideological tension analysis, this article reveals how three different media report the issue differently through developing different discourses that support their purpose; reflecting the contestation for power among them. While deconstructing the concept of the contribution that Megawati mystifies in her speech, this paper finds a need for a transvaluation on the conception of nationalism which in the end negates itself since it always has to do with a power struggle that has the potential to degenerate the Self and harm the Other.
\end{abstract}

Keywords: Critical discourse analysis; deconstruction; genre; ideology; nationalism.

\section{INTRODUCTION}

Megawati's critique for Indonesian millennials added a new act for the drama of the Job Creation Act, a law that President Joko Widodo had planned since his second presidential inauguration aimed to increase economic efficiency and overcome the overlapping contradictory characteristics of the previous rules. As a modification and combination of those rules, this act serves as legal protection for economic sectors that include job creation, UMKM (Micro, Medium, and Small-Scale Business), working hours, paid leave, and termination employment (Arnani, 2020). However, suspicions on the non-transparency of the act's explicit content and sudden legalization arose, triggering mass protests since January 2020 and culminating on October 6-8, 2020. The mass protest ended on October 13,2020 in chaos with the destruction of public facilities and numerous injured protesters due to a collision with the police ("Omnibus Law: Jokowi", 2020). During these times, many young people delivered harsh criticisms for governmental figures; one of them is the chief of DPR RI (The House of Representatives of the Republic of Indonesia), Puan Maharani Soekarnoputri who is also the daughter of the former Indonesian president and the leader of PDI-P (Indonesian Democratic Party of Struggle), Megawati Soekarnoputri. On October 28, 2020, during an online inauguration of her party's office, Megawati criticized young Indonesians for lacking contribution to the country ("Megawati: What contribution", 2020).
This paper intends to analyze this issue covered by three different media to discover the hidden realities the unconscious of the texts, so to speak- underneath the constructed discourses. The opposition between the young and, although implicitly, the senior generation that seems to be the central issue of the phenomenon seemingly invites this article to apply Jacques Derrida's (1978) deconstructive reading.

One thing to note in applying this mode of reading is that truth, for deconstructionists, is always contingent. Thus, a text, in general, has no center (or rather, the center is decentralized); there is no totalizing truth that can be claimed. If one claims any, therefore, it will only show the unsettling characteristic of the practical reality of a sign system: it is never innocent (Derrida, 2000; Burman \& MacLure, 2005). Any claims for totalizing truth of any discourses are then what Michel Foucault (2007) calls regimes of truth. Deconstruction, roughly, is a method to challenge these regimes. It does so by making use of the implication of Saussure's notion of the arbitrariness of language. A sign system, for Derrida, does not consist of signifier and signified, but signifier only (Haryatmoko, 2019) because it is différance -a process of deferring and differentiating one sign to another in an endless chain of significationthat decides the meaning of a sign (Derrida, 1978). Deconstruction, therefore, charges any claims for a totalized knowledge or meaning with fixation of a transcendental signified -a concept that one uses to determine the truthfulness and the universality of any 
systems of thought, e.g. structuralists' deep structure, Freud's phallus, theists' God, Descartes' cogito, etc. which results in the binary oppositions within the constructed discourses (e.g. men and women, mind and body, reason and emotion, etc.). These oppositions contain a metaphysical hierarchy -a value one can attribute to the concepts in the binary oppositions that positions one concept above the other. Deconstruction tries to disrupt this hierarchy by explicating the existence of binary oppositions to 1) gain a more apparent consciousness on the inconsistencies of a text, 2) open the chances for new interpretations, 3) raise critical awareness of what the text is hiding, and 4) construct a text that is alienated by itself (Haryatmoko, 2016, pp. 134-135).

Many scholars have applied deconstruction, but most of them either stop halfway or are still trapped within a particular ideology. Hafsah (2019), for example, finishes her research only by showing the existence of binary oppositions without challenging the universal claim and the hegemony that the texts preserve. Haikal (2016), on the other hand, uses dissemination mistakenly to justify morality which is the concept that critical thinkers should be suspicious about (Sindhunata, 2019). In another case, Rahman (2017) combines deconstruction with systemic functional grammar (SFG) under Fairclough's (2008) dialecticalrelational approach. However, the findings gathered from deconstructive analysis and the SFG analysis end up not complementing one another.

Despite its fallibility, Rachman's research has opened up a chance to combine deconstruction with other analytical tools to achieve a more critical result. This paper, then, aims to make use of this chance by applying several theories to push the results of deconstruction even further. This paper sees Sydney School's idea of a genre that views discourse as a staged and goal-oriented process (Martin \& Rose, 2008) profitable to understand the anatomy of the text. Meanwhile, Martin's (1992) dynamic perspective of ideological tension is also advantageous to gain insights about discursive agents' ideological positions. By combining deconstructive, genre, and ideological analyses; this paper aims to 1) understand how different each analyzed text deconstruct themselves, 2) uncover each media's position in the topology of ideology, and 3) unveil the socio-political reality underneath the discussion about the phenomenon in the analyzed news reports.

\section{METHODS}

This research is qualitative, with a naturalistic paradigm seeing reality as plural, contingent, and constructed which is in line with deconstructive principle (Burman \& MacLure, 2005; Haryatmoko, 2019). Under the perspective of critical discourse analysis, this research is considered descriptive comparative because it described and compared the hegemony found in the news report of Tempo, The Jakarta Post, and ExBulletin. These news reports, which served as the primary data, were selected through criterion-based technique (Strauss \& Corbin, 2003). The secondary data were articles and papers about the media's background information, the polemics of the Job Creation Act, and previous studies on deconstruction.

Before doing deconstructive analysis, this article analyzed each text using genre theory (Martin \& Rose, 2008) to understand their natures, anatomies, and goals. Its results were used to understand the texts' constructed ideologies which will be deconstructed. In applying the deconstructive analysis, this research adopted Haryatmoko's $(2016$; 2019) interpretation on Derrida that is complementary for critical discourse analysis. Different from other introductory texts on deconstruction that rarely cover the complexity of the theory and thus taking a risk in abstraction and labeling deconstruction as nihilist/skeptic practice, Haryatmoko's reading of Derrida results in a clear procedure of doing deconstruction that rescues it from the criticisms it has received. The steps are as follow:

1) Deciding the central theme as well as the central tension of the text.

2) Finding other binary oppositions promoting the central tension of the text which will serve as the evidences of constructed ideology of the text.

3) Reversing the metaphysical hierarchy of the binary oppositions.

4) Neutralizing the metaphysical hierarchy through dissemination (the dispersion of meaning) by highlighting the undécidable concepts.

The results from the deconstructive analysis on each coverage were then compared to understand the media's positions as ideological agents which resulted in the mapping of ideological topology. Combined with semantic dissemination of the texts' constructed ideologies, the topology would give insights into Indonesia's socio-political reality.

\section{FINDINGS AND DISCUSSION}

\section{Text 1: Deconstructing Contribution}

The first text entitled Megawati: What Contribution that Millennial Generation Has Made to the Country? is published by Tempo. It uses a lot of, in SFG's term, projections ( 7 out of 8 sentences employed) which suggests that the author's attitudes are heteroglossia, that is to say, the source of the attitudes is not from the author itself (see Martin \& White (2005) for more elaborate discussion on appraisal as one of SFG's systems of meaning- 
making). The story starts with Orientation that serves as the amalgamation of the following reported events. The First Event is that Megawati asks President Jokowi not to spoil Indonesian millennial. The asking itself is a result of Megawati's resentment because the millennial "could only stage demonstrations (para. 3)" which explains her doubt of the young people that they have made any contributions to the country. The next paragraph serves as the writer's comment that precedes the Second Event which is the destruction of public facilities during the mass protest. This comment seemingly puts Megawati as a caring mother by attributing a misery (one of the attitudes in appraisal analysis) in the clause "Megawati lamented public facilities that were destroyed (para. 4)". The writer ends the story with a Coda, summarizing that "demonstrations are permissible since the reform era. However, ... no regulations are allowing the destruction of public facilities (para. 6)." It is worth noting that the writer mentions the reform era, for this era marks Megawati's ascension to power in the government that lasts even until now. Thus, in terms of genre, this text is a combination of a news stories and narrative text.

Based on the text's anatomy, this paper sees questioning the millennial's contribution as the central topic of the text. The implicative reading of this story suggests that contribution, according to Megawati, should be made concretely, advantageous to the country, and in accordance with the national ideology. It implies that it is the previous generation, with figures like Megawati, who has made real contributions.

It is important to note that Megawati does not actually follow the original Strauss' \& Howe's (1991) generational theory in using the term millennial, and, interestingly, the authors of each analyzed text do not care to correct it. Megawati refers only to the young generation and compares them with the older one in which the latter receives the higher value in the metaphysical hierarchy. Thus, the first text constructs an ideology that Indonesian millennial lacks in making the contributions to the country. This act of antagonizing millennials is followed by other binary oppositions such as: having to meet face-to-face as opposed to acknowledging technologies; many contributions [implied] as opposed to lack of contribution; grant [indicated] as opposed to demonstration; supported [implied] as opposed to bullied; discipline [implied] as opposed to spoil; permitted as opposed to prohibited; Reform Era as opposed to New Order; and construction [indicated] as opposed to destruction. These binary oppositions create a narration that Megawati's generation, who does things traditionally (meeting face-to-face) has made more concrete contributions than the millennial who acknowledges advanced technologies. Once again, Megawati's lamentation on the destruction of public facilities implies that it is her generation who built them. Thus, concrete contributions are made, according to this narrative, by taking sides with the government, supporting instead of bullying its figures, creating social programs and even building infrastructures voluntarily to support the national ideology, and obeying the constitution. Another narrative that occurs, especially through the opposition between the New Order and the Reform Era, is that the text wants to give a tribute to Megawati, the prominent Reformation figure, and to remind its readers of the real contributions that Megawati has made: it is thanks to figures like Megawati, the suppression of national freedom in Indonesia during the New Order does no longer exist, it is thanks to Megawati, demonstrations are now allowed.

However, one must note that it is through acknowledging technologies the millennial becomes more aware of national issues. This awareness triggered them to give aspirations concerning the omnibus law. When the government ignored their collective aspirations, the millennials were forced to go down to the roads performing mass protests. When the government ignored them once again, they felt that they needed to do something 'out-of-the-box' to get its attention: from bullying the political figures to destroying public facilities. Here, the metaphysical hierarchy is reversed. Millennial has made actual contributions to the country through demonstration. Even the act of doing the restricted things such as bullying and destroying public facilities, in this light, is seen as somehow more virtuous than policy-making and facility-building that the government has done. It is important to note also that, by saying "let me know (para. 5)", Megawati asserts her superiority in a raging manner because the government led by her party was criticized. Is this reaction not similar to those employed by the figure(s) of the New Order?

After having the metaphysical hierarchy of the binary oppositions reversed, a deconstructionist needs to neutralize the metaphysical tension by making use of undécidable concepts. In the first text, they are "opined (para. 3)" and "lamented (para. 4)". The "opinion" here is undecidable because it exists between supporting and challenging, while the "lamentation" between victim and regret. Behind these concepts, the text hides something it neglects to acknowledge. The definition of contribution predeconstruction is assisting the government. At this point, a new question arises: are sympathy and empathy with events and social problems of the 
country not the fundamental forces that motivate one to contribute to one's country? Is a lamentation not the first symptom of contribution, for it is thanks to the act of lamentation that an opinion may arise? On the other hand, opinion can become a practice of problemsolving through critical analysis without prejudices to seek a rational argumentation and reflect upon the social problems and events -including governmental policies-in a clear conscience. Therefore, contribution may take the forms of lamentation and opinion. Is demonstration not the combination between the two? In the end, we can conclude that the text hides these characteristics of contribution to endorse Megawati.

\section{Text 2: Deconstructing Correctness}

The second analyzed text entitled 'I was correct': Megawati doubles down on jab at millennial generation is published by The Jakarta Post. Its title signals a firmer tension of pro-governmental attitude through the projected clause "I was correct" and the verb phrase "doubles down on jab" that endorses Megawati's correctness in criticizing millennials.

In terms of genre analysis, the text is rhetorical by playing with time ordering rather than argumentative structuring. It starts with Orientation mentioning how Megawati "brushed off (para. 1)" criticisms she got for her critique of Indonesian millennials. It then goes back to point out the beginning of the controversy when the statement was made. The text reports again on Megawati's clarification as the First Event, which illustrates the details of her reaction to the bullying she had received by clarifying that (millennial) entrepreneurs are not contributing to societal welfare since they care only for individual profits. Between Megawati's clarification and assertion of correctness (the Second Event), the author adds a commentary. This text ends by presenting the Third Event which is a flashback to Megawati's original statement on Indonesian millennials. Thus, similar to Text 1 , the second text is also a combination between a news stories and narrative text.

The genre analysis shows that The Jakarta Post seems to endorse the correctness of Megawati's millennial critique. Thus, the central binary opposition of the text is the correctness of Megawati's remark as opposed to the incorrectness of Indonesian millennials for bullying her. Although the constructed ideology is similar to the previous text, the other binary oppositions are different, they are:pleased as opposed to upset: $\boldsymbol{a}$ little as opposed to $\boldsymbol{a}$ lot; politicians [implied] as opposed to entrepreneurs; supported [implied] as opposed to bullied; Reform Era as opposed to New Order [implied]; real contribution [implied] as opposed to demonstration; construction [implied] as opposed to destruction; and allowed as opposed to restricted. These oppositions construct a narrative that Megawati is pleased -instead of getting mad- that her statement had triggered public discussion, implying Megawati's virtuous character while the text antagonizes millennial and entrepreneurs. Megawati regrets the fact that the very thing that is allowed because of the Reform Era, demonstration, is the only thing millennials seem to be passionate about, which results in the destruction of public facilities and the losses of financial and social welfare.

The text's depiction of the noble Megawati and the antagonistic millennials clearly suggests the superiority of the figures from the previous generation, especially those who now become governmental figures. However, their unwillingness for direct discussion with millennial and accepting criticisms would lead us to question what kind of nobility they try so hard to attribute for themselves. Is it not to say that, once again, The Reform Era that they are so proud of has now become the new New Order? Does not the text ignore the fact that mass demonstrations and the destructions of public facilities can be avoided if the government was willing to make an open discussion and reveal the detailed content of the act in public? Does it not also ignore the entrepreneurs' influence for creating employments and increasing the nation's income through taxation and investment? Here, therefore, the binary oppositions are reversed.

To neutralize the oppositions, it is important to notice that the undécidable concepts the second text employs are "comment," "discussion," and "controversy." The "comment" is undecidable because it functions as either to challenge or to support. The "discussion" implies, on the other hand, connotative meanings either to debate or to analyze. Meanwhile, the "controversy" is ambiguous in the judgement scale; it stands in between good and bad. After disseminating its semantic meaning, is correctness not a comment, a proposition to justify one's means, purposes, and intentions for power? Is the nature of a proposition not always debatable and controversial, thus it needs to be discussed further? Here, the endorsement of Megawati's correctness by The Jakarta Post is nothing but a desperate effort to show its loyalty to this prominent national figure.

\section{Text 3: Deconstructing Megawati's Asking to Jokowi}

The last text is written by a foreign online media named ExBulletin, a relatively new media covering UK and International. The article is entitled Joko Widodo asked 
not to spoil millennials, Megawati: what is their contribution to the nation? The Orientation of the text explains the result of the mass protests that "ended in chaos (para.1)." It is followed by a description of the demonstrations: their backgrounds (para. 2) and participants (para. 3). The text presents Megawati's critique towards Indonesian millennials as the last Event of the story. However, in reporting the event, the text projects only on Megawati's asking for President Jokowi "not to spoil the younger generation (para. 5)" and not on her statement about how the millennials lack actual contributions to the country. The structure of this text shows that it is a pure news stories. However, different from the previously analyzed texts, the central focus of the coverage is Megawati's asking for Jokowi not to spoil the young generation. Although the main binary opposition of this text is similar to the first text: the young as opposed to the senior generation; the number of supporting binary oppositions declines, they are: order [implied] as opposed to chaos; discipline [implied] as opposed to spoil; many contributions [implied] as opposed to lack of contribution; and seeing each other face-toface as opposed to knowing technology. These oppositions meant to show that Megawati's asking for Jokowi is a suggestion for the government to create stricter rules for disciplining the millennial to become a more obedient generation.

This text reports more minor details of the phenomenon by not mentioning the concrete happenings (destruction of public facilities). Instead, it uses the word "chaos (para. 1)" to somehow indicate that the national condition is uncontrollable and the government is to blame. Additionally, the author employs the term "spoil" more. These strategies are used to put Jokowi to the corner as if the demonstrations are Jokowi's faults. Surely, one needs to look back at Jokowi's performance. He has given opportunities for millennial to take significant positions in governmental institutions such as the chairs in the presidential staff ("Presiden Jokowi kenalkan", 2019). Jokowi has also tried to develop a closer relationship with millennial through self-imaging and one-to-one relations (Wibisono, 2018; Kristina, 2017). Are they not Jokowi's efforts to gain the young generation's awareness of and involvement in the national political environment, which are proven to be effective since the demonstration itself reflects political involvement, awareness, and, once again, contribution? In what ways, then, Jokowi spoils millennial? Here, the binary oppositions are reversed.

There are two undécidable concepts existing in the text: "response (para. 4)" and "expression (para. 6)" since they refer to an act with an ambiguous attitude (between positive and negative presupposition). These concepts open up new possible meanings for Megawati's asking to Jokowi. This asking can mean 1) a response to the destruction of public facilities during mass protests, 2) a response to the millennial who seems to fail in understanding the intention of the Job Creation Act, or even 3 ) a response made by a mother whose daughter had been bullied by almost all the youngsters of the nation. This asking can also mean an expression of power, an assertion that Megawati is the one who leads PDI-P -a party that backs up President Joko Widodo.

\section{Ideological Analysis: Media's Struggle for Power}

In their reports, each media does not challenge the validity of Megawati's arguments. They neither interview any Indonesian millennial figures nor provide any critical discussions about her statement. The deconstructive analysis of the first text indicates that Tempo tends to cover Megawati's back for the sake of keeping the power it has gathered. Tempo itself is established at the beginning of the New Order and claimed to be independent, a status that it claims to be consistent to maintain (Widiastuti, 2017). Tempo is a protagonist-right from the dynamic ideological perspective, which is to say that Tempo is an agent who tends to dissolve the issue out of the fear of losing power for debating it. This media's ideological position resonates with Goenawan Mohamad's, an important figure in Tempo, statement that Tempo's strategy is "not to be so close to the government but not to be distant from it (McCargo, 2003, p. 78)" for the sake of power and of information. It reveals that the cost of media independence, faute de mieux, is dependent on the ruling agent.

Compared to Tempo, The Jakarta Post is more radical in supporting Megawati. It even becomes so bold to betray its consumers, who are mostly millennials and entrepreneurs. Its position on the ideological typology is a protagonist-left because, by looking back at its background, The Jakarta Post is established for the interest of the government. Even after its reform in 1991 by becoming a pro-democracy newspaper, it still operates in the safety zone by avoiding governmental censorship (Tarrant, 2008). Hence, its editors-in-chief, from time to time, are often offered government's appointment. Some of them are Susanto Pudjomartono, who became Indonesia's ambassador to Australia ("Former editor and diplomat" 2015) and Endy Bayuni, who is now the chair of Indonesia's Antara state news agency ("Post' welcomes new" 2018). It seems that The Jakarta Post's drive for power is more intense than that of Tempo, which just wants to keep its stability. 
Meanwhile, foreign media like ExBulletin has nothing to lose. Challenging the issue, it attracts the antigovernment sides such as the radical Islamic fundamentalists and the supporters of the opposition parties to read its articles. Therefore, the way ExBulletin develops its discourses is closely related to its marketing strategy, establishing itself a position as an antagonist-left: an agent who challenges the issue and getting power in doing so. The differences in establishing a discourse between Tempo, The Jakarta Post, and ExBulletin serve as the proofs that the stories the media presents to its readers are the products of manipulations based on concrete events driven by ideological motivations (Karomami, 2004).

Concerning the linguistic template of ideological agents, this article's results support and, at the same time, challenge the findings of Santosa, Priyanto, \& Nuraeni (2014). On the one hand, it is true that projected clauses, groups, and lexes systems can indicate the discursive agent's ideological position. However, this research shows that it is not just the antagonists who develop one-sided arguments. The writers of Text 1 and 2, the protagonists in this issue, also employ one-sided arguments as their discursive strategy. Additionally, the combination of genres does not also always indicate the ideological position. Therefore, this research suggests that the use of different genres and registers has to do with the intensification of power struggle; linguistic structure and/or form alone cannot determine one's ideological position, an analyst must investigate what function that the structure and/or form may carry out. In so doing, an SFG analyst will no longer be fixated on its transcendental signified, that is, the linguistic structure/form (be it genre, registers, etc.).

\section{Towards A New Perspective of Nationalism and Its Obstacle}

The conflict between the old and the young generation concerning national contribution may indicate a need for, using a Nietzschean term, a transvaluation on the concept of nationalism. The emerging implication from the discussed phenomenon and discourses is that contribution is the key to gaining a national identity. Since the idea of contribution has been deconstructed in the analysis, Megawati and her supporters view contribution as a signified absence: a way the discourse constitutes a meaning system by simultaneously structuring such meanings based on inclusion and exclusion (Mumby \& Stohl, 1991). For them, a contribution is only worth attributed to those who support them by including them as the member of their group. Moreover, their highlight on seniority shows that they believe in traditional nationalism. In this belief, national identity is a fixed concept and given by nature (Sutherland, 2011). Practices of exploiting primordial symbols and claims of being the elder's representation are practically effective to gain followers in this kind of nationalism.

The deconstructive analysis has considered demonstration as a practice of contribution that Indonesian youngsters can use to pursuit legitimacy for their national identity. This practice reflects a new belief concerning national identity: neo-nationalism (Sutherland, 2011). In this perspective, national identity is acknowledged through legitimizing one's act that shows the collective interest (Keating, 2001). Dealing with this issue, in a similar direction, Derrida (1998) places (national) identity as a fluctuation of both the Self and the Other, that is to say, the concept of (national) identity is also constructed through différance: deferring and differentiating the Self from the Other. Thus, national identity is fluid; one is always both the Self and the Other (Hawa, 2014). Similarly, Sunardi (2015) states that nationalism is not a natural identity as a mode of existence in a community. Nationalism "is an act of collective imagining ... [that] ... needs to be invented and reinvented in the modern society (p. 2)."

Neo-nationalism gives way for Indonesia to become a more tolerant country that embraces plurality and diversity. However, the distinction between traditional nationalism and neo-nationalism will lead to its own deconstruction since the establishment of any concepts about nationalism is always driven by, to quote Nietzsche (2017), the will to power. Nationalism will always have the potential to degenerate the Self through excessive fanaticism and thus harm the Other in a battle of domination. This paper ends up supporting Horkheimer's (2004) pessimism arguing that, in this case, one's effort to justify or to create a better conception on nationalism will meet its greatest obstacle, that is the very effort of justification or creation itself.

\section{CONCLUSION}

Using genre, deconstructive, and ideological analyses, this paper shows how three media cover Megawati's critique for millennial differently through stages they structure, binary oppositions they employ, ideologies they construct, undécidable concepts they hide, and ideological positions they are in. The motivation behind the different way of covering the issue has to do with their power struggles: Tempo wants to keep the power it has gained by supporting the government, The Jakarta Post aims to gain more power by assisting the government, and ExBulletin intends to gain more power by bending the issue. 
This paper finds a more complex truth behind the analyzed discourses. There has been a greater tension among Indonesians (in this case, between the young and the old generation, but the occurring tension may not restrict to this opposition only. There is a more urgent conflict between conservative -represented by, among others, radical Islamic fundamentalists- and liberal Indonesians) which reflects an urgency to transvalue the notion of nationalism following Indonesia's plural and diverse characteristics. It may comply with neo-nationalism, which is in line also with Derrida's (1998) concept of (national) identity. According to neo-nationalism, national identity is legitimized through a collective acknowledgement, instead of a rigid historical heritage. The act of demonstration then shows Indonesians' effort to gain a legitimation for national identity as true Indonesian. However, the fact that power operates within every discourse and knowledge lays a foundation for a pessimistic belief in the notion of progress. In this case, one's effort to transvalue nationalism for a better purpose and collective interests, in the end, meets its greatest obstacle, that is, the effort itself. Thus, this article ends in a Platonian aporetic dialogue to trigger more comprehensive discussions and analyses on the complex and unsettling nature of nationalism and identity.

\section{Analyzed Texts}

'I was correct': Megawati doubles down on jab at millennial generation. (2020, October 28). The Jakarta Post. https://www.thejakartapost.com/news/2020/10/ 28/workers-students-return-to-street-for-new-jobslaw-protest.html

Megawati: What contribution millennial generation has made to the country? (2020, October 28). Tempo. https://en.tempo.co/read/1400333/megawati-whatcontribution-that-millennial-generation-has-made-tothe-country

Joko Widodo asked not to spoil millennials, Megawati: what is their contribution to the nation? (2020, October 28). ExBulletin. https://exbulletin.com/politics/503542/.

\section{REFERENCES}

Arnani, M. (2020, October 4). Mengenal apa itu omnibus law dan seluk beluknya. Kompas. https://www.kompas.com/tren/read/2020/10/04/ 170500865/mengenal-apa-itu-omnibus-law-danseluk-beluknya-?page=all

Burman, E. \& MacLure, M. (2005). Deconstruction. In B. Somekh \& C. Lewin (Eds.), Research methods in the social sciences, (pp. 284-292). London: Sage Publication.
Derrida, J. (1978). Writing and difference (A. Bass, Trans.). Chicago: Chicago University Press.

Derrida, J. (1998). Monolingualism of the other or the prosthesis of origin (P. Mensah, Trans.). California: Stanford University Press.

Derrida, J. (2000). Structure, system, and play in the discourse of the human sciences. In D. Lodge \& N. Wood. (Eds.), Modern criticism and theory: a reader (2nd ed., pp. 89-103). Singapore: Longman.

Former editor and diplomat Susanto Pudjomartono passes away. (2015, January 14). The Jakarta Post. https://www.thejakartapost.com/news/ 2015/01/14/former-editor-and-diplomat-susantopudjomartono-passes-away.html

Foucault, M. (2007). Truth and power. In C. J. Calhoun (Ed.), Contemporary sociological theory (pp. 203-218). New Jersey: Blackwell Publishing.

Hafsah, S. (2019). The short story "I Want My Son to Become a Murderer" in deconstructive analysis. Ethica Lingua: Journal of Language Teaching and Literature, 6(2), 45-58. https://doi.org/ 10.30605/25409190.v6.45-58

Haikal, M. (2016). Dekonstruksi wacana censorship pada teks antologi kepustakawanan Indonesia [Deconstructing censorship discourse on the anthology of librarianship]. [Bachelor's thesis, Universitas Islam Negeri Syarif Hidayatullah]. UIN Syarif Hidayatullah Institutional Repository. https://repository.uinjkt.ac.id/dspace/handle/123 $456789 / 32203$

Haryatmoko, (2016). Membongkar rezim kepastian: Pemikiran kritis post-strukturalis [Dismantling the regime of certainty: Post-structuralis critical thinking]. Yogyakarta: Kanisius.

Haryatmoko, (2019). Critical discourse analysis (analisis wacana kritis): landasan teori, metodologi, dan penerapan [Critical discourse analysis: Theoretical foundation, methodology, and its application] (3rd ed.). Depok: Rajawali Press.

Hawa, S. (2014). Through the eye of the other. Arab Studies Quarterly, 36(3), 201-219. https://doi.org/ 10.13169/arabstudquar.36.3.0201.

Horkheimer, M. (2004). Eclipse of reason. London and New York: Continuum.

Karomami, H. (2004). Pengaruh ideology terhadap wacana berita dalam media massa [Influences of ideologies on news discourse in mass media]. MediaTor, 5(1), 39-45. https://doi.org/10.29313/ mediator.v5i1.1096

Keating, M. (2001). Plurinational democracy: Sateless nations in a post-sovereignty era. Oxford: Oxford University Press.

Kristina, D. (2017). Bahasa persuasif dalam public relations [Persuasive language in public relations]. Jakarta: Akademi Indonesia Sekolah Darurat Kartini. 
Martin, J. R. (1992). English text: System and structure. Philadelphia: John Benjamins.

Martin, J. R. \& Rose, D. (2008). Genre relations: Mapping culture. London: Equinox.

McCargo, D. (2003). Media and politics in Pacific Asia. London: Routledge.

Megawati: What Contribution that Millennial Generation Has Made to the Country? (2020, October 28). Tempo. https://en.tempo.co/read/1400333/ megawati-what-contribution-that-millennialgeneration-has-made-to-the-country

Mumby, D. K. \& Stohl, C. (1991). Power and discourse in organization studies: Absence and the dialectic of control. Discourse and Society, 2(3), 313-323. https://doi.org/10.1177\%2F095792659 1002003004

Nietzsche, F. (2017). The will to power: selections from the notebooks of the 1880 s $(\mathrm{R}$. K. Hill \& M. A. Scarpitti, Trans.) London: Penguin Books.

Omnibus Law: Jokowi teken UU Cipta Kerja - hal-hal yang perlu anda ketahui dan beberapa kontroversinya [Omnibus Law: Jokowi signed the Job Creation Act - what you need to know and some controversies]. (2020, November 13). BBC. https://www.bbc.com/indonesia/indonesia51542411

'Post' welcomes new chief editor. (2018, January 30). The Jakarta Post. https://www.thejakartapost. com/news/2018/01/30/post-welcomes-newchief-editor.html

Presiden Jokowi kenalkan 7 milenial sebagai staf khusus baru [President Jokowi introduced 7 millenials as new special staffs]. (2019, November 21). Kementerian Sekretariat Negara Republik Indonesia [Ministry of State Secretariat of the Republic of Indonesia]. https://setneg.go.id/baca/ index/presiden_jokowi_kenalkan_7_milenial_se bagai_staf_khusus_baru

Rahman, A. R. (2017). Dekonstruksi makna cantik dalam iklan produk kecantikan Pond's White
Beauty: analisis wacana kritis [Deconstructing the meaning of beautiful in beauty product advertisement Pond's White Beauty: Critical Discourse Analysis]. Humanitatis: Journal on Language and Literature, 4(1), 74-85.

Santosa, R., Priyanto, A. D., \& Nuraeni, A. (2014). Genre and register of antagonist's language in media: An appraisal study of Indonesian newspapers. K@ta, 16(1), 23-36. https://doi.org/10. 9744/kata.16.1.23-36

Sindhunata, G. P. (2019). Dilema usaha manusia rasional: teori kritis sekolah Frankfurt Max Horkheimer \& Theodor W. Adorno [Dilemma of rational being' efforts: Crticial theory of Frankfurt school Marx Horkheimer \& Theodor W. Adorno]. Jakarta: Gramedia.

Sunardi, D. (2015). A critical comparative reading of nationalism in Pramoedya A. Toer and Ngugi wa Thiong’o. K@ta, 17(1), 1-18. https://doi.org/10. 9744/kata.17.1.1-18

Strauss, W. \& Howe, N. (1991). Generations: the history of America's future, 1584 to 2069. New York: Harper Perennial.

Strauss A. \& Corbin, J. (1990). Basics of qualitative research: Techniques and procedures for developing grounded theories. London: Sage Publishing.

Sutherland, C. (2011). Nationalism in the twenty-first century: Challenges and responses. Basingstoke: Palgrave Macmillan.

Tarrant, B. (2008). Reposting Indonesia: The Jakarta Post story. Jakarta: Equinox Publishing.

Wibisono, N. (2018, October 22). Jokowi yang menatap pemilih milenial [Jokowi who is looking at millennial voters]. tirto.id. https://tirto.id/ jokowi-yang-menatap-pemilih-milenial-c8ie

Widiastuti, R. (2014). Produksi berita Tempo: telaah antropologi media [The news production of Tempo]. [Unpublished master's thesis]. Universitas Gajah Mada. 